Zeszyty Naukowe Szkoły Głównej Gospodarstwa Wiejskiego w Warszawie

Problemy Rolnictwa Światowego tom 18 (XXXIII), zeszyt 3, 2018: 144-155

DOI: $10.22630 /$ PRS.2018.18.3.73

Dominika Jakubowska $^{1}$, Tomasz Wierzejski ${ }^{2}$

Uniwersytet Warmińsko-Mazurki w Olsztynie

\title{
Ocena koncentracji produkcji żywności regionalnej i tradycyjnej w Polsce i krajach Unii Europejskiej
}

\section{Evaluation of Market Concentration of Regional and Traditional Food Production in Poland and European Union Countries}

\begin{abstract}
Synopsis. Celem pracy była ocena koncentracji produkcji żywności regionalnej i tradycyjnej w Unii Europejskiej (UE) ze szczególnym uwzględnieniem Polski. Analizy dokonano na podstawie danych pochodzących z europejskich baz DOOR, E-BACCHUS, E-SPIRIT DRINKS oraz danych IJHARS. Opisano i przeanalizowano różne kategorie regionalnych i tradycyjnych produktów zarejestrowanych w Polsce jak i innych krajach UE wykorzystując indeks koncentracji Herfindahhl-Hirschman. Otrzymane wyniki dowiodły, że koncentracja produkcji żywności regionalnej i tradycyjnej w UE jest duża, a większość zarejestrowanych oznaczeń geograficznych produktów pochodzi z krajów basenu Morza Śródziemnego, na które przypada niemal trzy czwarte wszystkich unijnych rejestracji. Polska posiada niewielki udział $\mathrm{w}$ analizowanym rynku. W ujecciu regionalnym $\mathrm{w}$ Polsce odnotowano względnie wysoką koncentrację produkcji. Wyraźnie wyższą wartość wykazano dla koncentracji producentów tych produktów.
\end{abstract}

Słowa kluczowe: systemy ochrony jakości, oznaczenia geograficzne, produkcja żywności, koncentracja rynku

\begin{abstract}
The purpose of the work was to assess the concentration of regional and traditional food production in the European Union (EU) with particular emphasis on Poland. The analysis was made on the basis of data from the European DOOR databases, E-BACCHUS, E-SPIRIT DRINKS and IJHARS data. Various categories of regional and traditional products registered in Poland and other EU countries were described and analyzed using the Herfindahhl-Hirschman concentration index. The results obtained showed that the concentration of regional and traditional food production in the EU is high, and the majority of registered geographical indications originate from the Mediterranean, which accounts for almost three quarters of all EU registrations. Poland has a small share in the analyzed market. In regional terms, Poland has a relatively high concentration of production. A clearly higher value was demonstrated for the concentration of producers of these products.
\end{abstract}

Key words: quality protection systems, geographical indications, food production, market concentration

JEL Classification: L11, O12

\section{Wprowadzenie}

Postępująca globalizacja na europejskim rynku rolno-spożywczym doprowadziła do zwiększonej konkurencji ze strony dużych przedsiębiorstw, w szczególności przedsiębiorstw

\footnotetext{
${ }^{1}$ dr, Katedra Mikroekonomii, Wydział Nauk Ekonomicznych UW-M, Pl. Cieszyński 1, bl. 43, 10-719 Olsztyn, e-mail: dominika.jakubowska@uwm.edu.pl; https://orcid.org/0000-0002-2797-9680

${ }^{2} \mathrm{dr}$, e-mail: tomasz.wierzejski@uwm.edu.pl; https://orcid.org/0000-0003-1185-5197
} 
wielonarodowych, a liberalizacja handlu spowodowała zmniejszenie ochrony rynku (Gellynck i in., 2012). Spowodowało to także wzrost zainteresowania konsumentów jakością żywności, nie tylko w odniesieniu do produktów o wyższej jakości zdrowotnej, ale także ich miejsca pochodzenia i sposobu wytworzenia. Konsumenci wyrażają pozytywne emocje wobec produktów, których miejsce produkcji jest bliżej miejsca konsumpcji (Kumpulainen i in., 2018), i większy poziom zaufania do żywności krajowej i regionalnej, niż do produktów o nieznanym lub globalnym pochodzeniu (Lobb i Mazzocchi, 2007). Uczciwość, tradycja, świeżość, bezpieczeństwo, lepsza jakość, etyczna produkcja i ochrona środowiska to cechy przypisywane żywności tradycyjnej i regionalnej (Feldemann i Hamm, 2015; Campbell i in., 2014; Motta i Sharma, 2016). Tak więc, regionalne i tradycyjne produkty żywnościowe, związane ze szczególnym obszarem geograficznym czy tradycyjną metodą produkcji mogą odgrywać znaczącą rolę na rynku rolno-spożywczym i są coraz częściej wybierane przez konsumentów, którzy odnajdują w nich „powrót do tradycji” (Gellynck i in., 2012). Te zmiany dają możliwości rozwoju małym firmom działającym na rynkach niszowych. Wytwarzane rzez nich produkty przyczyniaja się do dywersyfikacji dostaw produktów żywnościowych będących przedmiotem handlu na rynkach UE. Mając na uwadze, że producenci żywności tradycyjnej i regionalnej to zazwyczaj mikro i średnie przedsiębiorstwa, często firmy rodzinne, wspieranie ich działalności może zachęcać lokalne środowiska biznesowe do walki z konkurencją dużych producentów żywności (Stanciu, 2015). Pracochłonne i czasochłonne metody produkcji żywności są alternatywą dla standaryzacji i ujednolicania produkcji, a potrzeba zachowania bioróżnorodności w produkcji roślinnej i zwierzęcej państw stała się głównym powodem wprowadzenia przez Unię Europejską systemu ochrony produktów tradycyjnych i regionalnych (Gulbicka, 2014).

\section{Ochrona produktów tradycyjnych i regionalnych w Europie}

Producenci rolni w Unii Europejskiej (UE) mają możliwość ubiegania się o rejestracje nazw produktów w ramach oznaczeń geograficznych (OG). Ochrona nazw geograficznych oznaczających produkty rolne istnieje od końca XX w. i jest ważnym instrumentem polityki UE w zakresie jakości. Ma na celu utrzymanie różnorodność produkcji rolnej w UE, a także daje możliwość wyróżnienia produktów na rynkach krajowych i międzynarodowych, przyczyniając się do poprawy konkurencyjności i rentowności działalności ich wytwórców (Grębowiec, 2017). Wykorzystując owe oznaczania podkreślają oni związek produktu z danym krajem, regionem czy miejscowością, co może być dla kupującego głównym czynnikiem wyboru towaru. $\mathrm{W}$ ostatnich latach, w związku z umasowieniem produkcji wielu towarów, konsumenci coraz bardziej doceniają oryginalne produkty pochodzące z konkretnych miejsc w kraju i na świecie, cechujące się niepowtarzalnymi właściwościami (Pieniak i in., 2009; Dansero i Puttilli, 2013; Fernández-Ferrín i in., 2018).

$\mathrm{W}$ polskim prawie nie ma prawnej definicji oznaczenia geograficznego. Jednakże oznaczenia geograficzne są związkiem symbolu o treści geograficznej z towarem, który jest odbierany przez nabywcę jako zespół informacji o towarze, w tym zwłaszcza o jego pochodzeniu z pewnego miejsca geograficznego ${ }^{3}$. Oznaczenia geograficzne mają więc za zadanie chronić zarówno odbiorcę, jak i producenta przed nieuczciwymi praktykami handlowymi polegającymi na oznaczaniu towarów znakami wprowadzającymi odbiorców

\footnotetext{
${ }^{3}$ https://www.uprp.pl/oznaczenia-geograficzne/Lead05,36,1806,4,index,pl,text/
} 
w błą co do pochodzenia, rodzaju czy jakości towaru. Jednak ochrona nie zawsze przekłada się na sukces gospodarczy, ponieważ wymaga od producentów przestrzegania pewnych zasad specyfikacji, co może wiązać się z dodatkowymi kosztami.

Wspólnotowy system ochrony oznaczeń geograficznych obejmuje oznaczenia geograficzne produktów rolnych i środków spożywczych oraz oznaczenia geograficzne napojów spirytusowych. Prawodawstwo UE zapewnia ochronę oznaczeń geograficznych w odniesieniu do (European Commission, 2013):

- Win: system rozpoczęty w latach $70 . \mathrm{XX}$ w. w ramach wspólnej organizacji rynku wina, został zmieniony w 2008 r. w kontekście reformy sektora wina, aby przyjąć zasady prawodawstwa dotyczącego produktów rolnych i środków spożywczych.

- Napojów spirytusowych: system powstał w 2008 r. po reformie przepisów dotyczących definicji, opisu, prezentacji, etykietowania i ochrony oznaczeń geograficznych napojów spirytusowych. Wcześniej nazwy były wymienione i chronione w ustawodawstwie dotyczącym napojów spirytusowych.

- Produktów rolnych i środków spożywczych: zharmonizowane ramy regulacyjne dla rejestracji oznaczeń geograficznych w UE opracowano w 1992 r.

- Aromatyzowanych produktów winiarskich: obecnie omawiane są nowe zharmonizowane ramy regulacyjne.

Aktualne rozporządzenie $\mathrm{w}$ sprawie systemów jakości dla produktów rolnych i środków spożywczych (rozporządzenie (UE) nr 1151/2012) weszło w życie 3 stycznia 2013 r. Stworzona została także unijna baza danych (DOOR) dla produktów rolnych i artykułów spożywczych zarejestrowanych jako Chroniona Nazwa Pochodzenia (ChNP), Chronione Oznaczenie Geograficzne (ChOG) lub Gwarantowana Tradycyjna Specjalność (GTS), jak również nazw, dla których wniosek o rejestrację został złożony w Komisji Europejskiej.

Ustawodawstwo unijne uznaje dwie formy ochrony oznaczeń geograficznychChronioną Nazwę Pochodzenia (ChNP) i Chronione Oznaczenie Geograficzne (ChOG), dostępne dla produktów rolnych i środków spożywczych oraz win. ChOG można również stosować do napojów spirytusowych i win aromatyzowanych, ale ChNP nie jest dla nich dostępne. Oprócz tego istnieje trzecia forma ochrony - Gwarantowana Tradycyjna Specjalność (GTS), która podkreśla tradycyjny proces produkcji (tab. 1). Chociaż GTS nie jest uważana za oznaczenie geograficzne, ponieważ nie wiąże bezpośrednio produktu z miejscem, należy je uwzględnić, ponieważ jest ona częścią systemu jakości UE, służąc podobnym celom. Oznaczenie to zostało ustanowione w celu ochrony tradycyjnych metod produkcji i receptur, pomagając producentom produktów tradycyjnych $\mathrm{w}$ marketingu i przekazując konsumentom wartość dodaną ich tradycyjnych receptur i produktów. 
Tabela 1. Trzy systemy ochrony nazw produktów regionalnych i tradycyjnych

Table 1. Three systems to protect the names of regional and traditional products

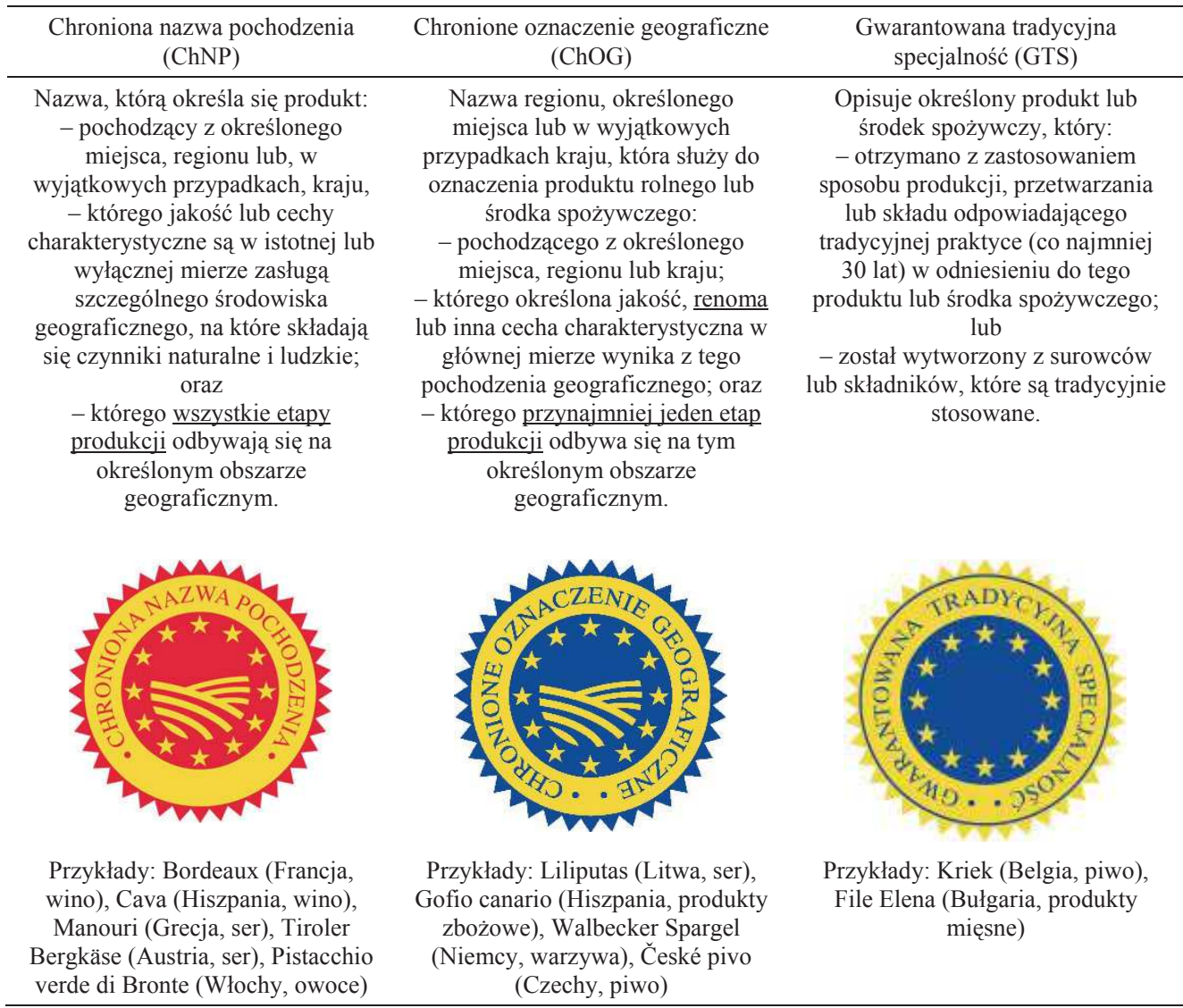

Źródło: opracowanie własne na podstawie danych Ministerstwa Rolnictwa i Rozwoju Wsi oraz Komisji Europejskiej.

W ramach unijnego systemu jakości, żywność lub napój pochodzące z UE lub spoza UE, zarejestrowane na poziomie europejskim, otrzymują ochronę prawną przed imitacją w całej UE. Każdy indywidualny producent żywności lub grupa producencka może ubiegać się o zarejestrowanie nazwy żywności chronionej. Może to potrwać do kilku lat zanim nazwa będzie prawnie chroniona. Jednak ochrona jest udzielana na czas nieokreślony od momentu przyznania jej przez UE. Używanie nazwy chronionej, czy metody produkcji musi być kontrolowane co najmniej raz na trzy lata przez odpowiedni organ kontrolny. Producent w UE przesyła wniosek do swojego organu krajowego, a producent spoza UE przesyła wniosek bezpośrednio do Komisji Europejskiej. Jednak produkty spoza UE muszą być już chronione w ich kraju pochodzenia (rys. 1) 


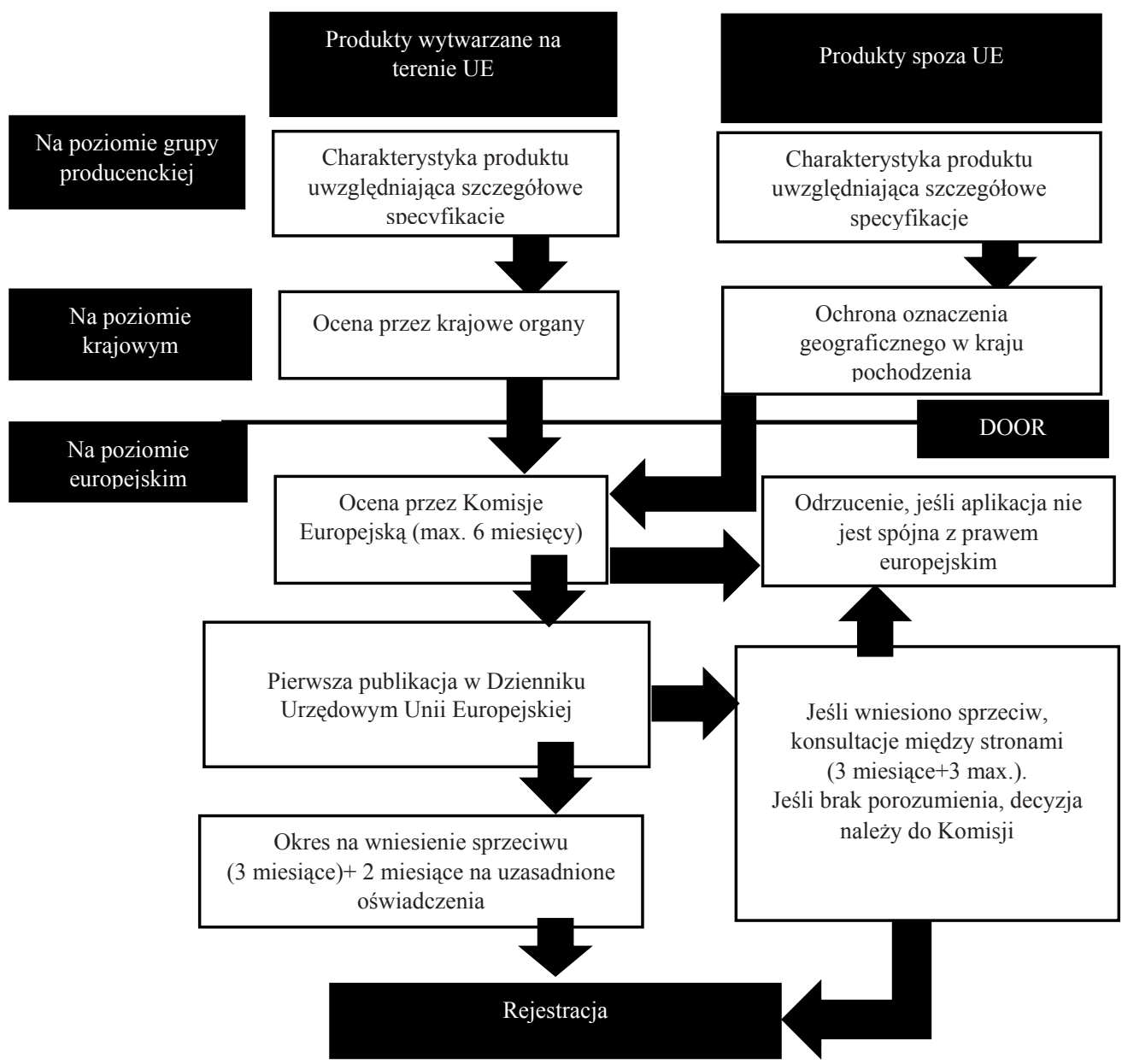

Rys. 1. Proces rejestracji oznaczeń geograficznych

Fig. 1. Registration process for geographical indications

Źródło: HORIZON, Market Intelligence, 2016.

Wytwarzanie produktów posiadających Chronioną Nazwę Pochodzenia, Chronione Oznaczenie Geograficzne lub Gwarantowaną Tradycyjną Specjalność daje producentom możliwość zwiększenia rentowności i konkurencyjności swojej działalności, a także ochrony integralności produktów przed niewłaściwym wykorzystaniem i fałszowaniem. Należy jednak pamiętać, iż rejestracja nazwy jako ChNP czy ChOG sama w sobie nie gwarantuje sukcesu producentom. Znak unijny na etykiecie produktu może jednak zwiększać jego widoczność, a także gwarantować ochronę przed nadużywaniem nazwy produktu. 


\section{Metodyka badania}

Celem pracy była ocena koncentracji produkcji żywności regionalnej i tradycyjnej w Unii Europejskiej (UE) ze szczególnym uwzględnieniem Polski. Do oceny struktury rynku pod kątem jego konkurencyjności wykorzystywane są miary koncentracji rynków. Jednym z najczęściej stosowanych wskaźników w tym zakresie jest Indeks HerfindahlaHirschmana (HHI) (Kwiatkowska, 2014; Matczak, 2016). Geneza jego zastosowania wywodzi się z amerykańskich instytucji antymonopolowych, jak też instrumentarium wykorzystywanego przez Komisję Europejską w ramach prowadzonej polityki konkurencji Unii Europejskiej. Konstrukcja HHI opiera się na sumie kwadratów udziałów wszystkich podmiotów na rynku (przedsiębiorstw, producentów):

$$
H H I=\sum_{i=1}^{n} p_{i}^{2}
$$

gdzie $p_{i}$ oznacza relatywny udział i-tego podmiotu w rynku, a $n$ to całkowita liczba podmiotów na rynku.

Indeks HH można poddawać zarówno analizie statycznej jak i dynamicznej. W ujęciu statycznym przyjmuje on wartości z przedziału (0 do 10000), gdzie skrajny poziom oznacza istnienie rynku monopolistycznego. Wartości pośrednie, wyznaczające poziomy koncentracji rynku, są odmiennie definiowane na rynkach amerykańskim i europejskim (tab. 2). Z uwagi na fakt, że w badaniu poddano analizie rynek państw Unii Europejskiej, do oceny efektów rynkowych procesów integracyjnych zastosowano wytyczne UE.

Tabela 2. Ocena efektów rynkowych procesów integracyjnych na podstawie wskaźnika HHI w Stanach Zjednoczonych i Europie

Table 2. Evaluation of the market effects of integration processes based on the HHI index in the United States and Europe

\begin{tabular}{l|cc}
\hline \multicolumn{1}{c|}{ Rynek } & USA & UE \\
\hline NIESKONCENTROWANY & $<1500$ & $<1000$ \\
integracja nie ma negatywnego wpływu na konkurencyjność & & $1000-2000$ \\
UMIARKOWANIE SKONCENTROWANY & $1500-2500$ & $>2000$ \\
integracja może mieć negatywny wpływ na konkurencyjność & $>2500$ & \\
WYSOKO SKONCENTROWANY & & \\
integracja posiadać będzie negatywny wpływ na konkurencyjność
\end{tabular}

Źródło: Horizontal Merger Guidelines (2010), Wytyczne w sprawie oceny horyzontalnego połączenia przedsiębiorstw...(2004/C31/03).

Źródłem danych były informacje pochodzące $\mathrm{z}$ europejskich baz DOOR, EBACCHUS, E-SPIRIT DRINKS oraz danych Inspekcji Jakości Handlowej Artykułów Rolno-Spożywczych. Zaprezentowano ilościowy udział w rynku unijnym produktów zarejestrowanych jako Chroniona Nazwa Pochodzenia (ChNP), Chronione Oznaczenie Geograficzne (ChOG), Gwarantowana Tradycyjna Specjalność (GTS) z uwzględnieniem kategorii produktów, jak również poszczególnych państw członkowskich. Przedstawiono także wartości indeksu HHI w trzech systemach ochrony nazw produktów regionalnych i tradycyjnych w UE. Szczegółowej analizie poddano poszczególne województwa w Polsce z uwzględnieniem liczby producentów i wytwarzanych przez nich produktów. 


\section{Koncentracja produkcji żywności regionalnej i tradycyjnej w UE}

Do stycznia 2018 r. zarejestrowano w Unii Europejskiej 1421 produktów, 2891 win i 268 napojów spirytusowych, które posiadają oznaczenie ChNP, ChOG lub TGS (bazy danych DOOR, E-BACCHUS, E-SPIRIT DRINKS) (tab. 3). W ramach tej grupy znajduja się produkty wytwarzane poza UE, w tym 10 zarejestrowanych z Chin, 4 z Tajlandii, 3 z Turcji i 11 z innych poza europejskich krajów.

Tabela 3. Liczba produktów zarejestrowanych jako ChNP, ChOG, GTS w UE (wg kategorii) na dzień 17.01.2018 Table 3. Number of products classes registered as PDOs, PGIs and GTS in EU countries - (as of 17 January 2018)

\begin{tabular}{|c|c|c|}
\hline Klasa/ Grupa produktów tradycyjnych & $\begin{array}{l}\text { Liczba zarejestrowanych } \\
\text { produktów w UE }\end{array}$ & $\begin{array}{l}\text { Liczba zarejestrowanych } \\
\text { produktów w Polsce }\end{array}$ \\
\hline \multicolumn{3}{|c|}{ ChNP, ChOG } \\
\hline 1.1. Mięso świeże & 164 & 1 \\
\hline 1.2. Produkty wytworzone na bazie mięsa & 174 & 4 \\
\hline 1.3. Sery & 234 & 5 \\
\hline 1.4. Inne produkty pochodzenia zwierzęcego & 44 & 4 \\
\hline 1.5. Oleje i thuszcze & 133 & 0 \\
\hline 1.6. Owoce, warzywa i zboża świeże lub przetworzone & 383 & 9 \\
\hline 1.7. Świeże ryby i owoce morza & 47 & 1 \\
\hline 1.8. Inne produkty & 64 & 0 \\
\hline 2.1. Piwo & 20 & 0 \\
\hline 2.4. Chleb i wyroby piekarnicze & 77 & 6 \\
\hline 2.5. Naturalne gumy & 2 & 0 \\
\hline 2.6. Pasta musztardowa & 2 & 0 \\
\hline 2.7. Makarony & 10 & 0 \\
\hline 3.1. Siano & 1 & 0 \\
\hline 3.2. Olejki eteryczne & 4 & 0 \\
\hline 3.4. Koszenila & 1 & 0 \\
\hline 3.5. Kwiaty i rośliny ozdobne & 3 & 0 \\
\hline 3.6. Welny & 1 & 0 \\
\hline \multicolumn{3}{|c|}{ GTS } \\
\hline 1.1. Mięso świeże & 3 & 0 \\
\hline 1.2. Produkty wytworzone na bazie mięsa & 15 & 3 \\
\hline 1.3. Sery & 6 & 0 \\
\hline 1.4. Inne produkty pochodzenia zwierzęcego & 3 & 0 \\
\hline 1.5. Oleje i thuszcze & 1 & 1 \\
\hline 1.6. Owoce, warzywa i zboża świeże lub przetworzone & 1 & 0 \\
\hline 1.7. Świeże ryby i owoce morza & 3 & 0 \\
\hline 1.8. Inne produkty & 4 & 4 \\
\hline 2.1. Piwo & 6 & 0 \\
\hline 2.3. Wyroby cukiernicze, chleb & 14 & 1 \\
\hline 2.4. Makarony & 1 & 0 \\
\hline Suma & 1421 & 39 \\
\hline
\end{tabular}


Najliczniej reprezentowaną grupą produktów są owoce, warzywa i zboża (383), sery (234), produkty mięsne (174), świeże mięso (164) i oleje (133). Wiodącymi państwami członkowskimi w ilości zarejestrowanych produktów są Włochy, Francja, Hiszpania, Portugalia i Grecja (tab. 4). W każdym z tych państw zarejestrowanych jest ponad 100 produktów, a najwięcej we Włoszech - niemal 300. W efekcie 979 oznaczeń z regionu Europy Południowej stanowi 70\% całego analizowanego rynku w UE.

Tabela 4. Liczba produktów zarejestrowanych jako ChNP, ChOG, GTS w Unii Europejskiej (wg państw) na dzień 17.01.2018

Table 4. Number of products registered as PDOs, PGIs and GTS in EU countries - (as of 17 January 2018)

\begin{tabular}{|c|c|c|c|c|c|c|c|c|}
\hline \multirow{2}{*}{ Państwo } & \multicolumn{3}{|c|}{ Produkty regionalne i tradycyjne } & \multirow{2}{*}{ Suma } & \multicolumn{4}{|c|}{$\operatorname{Pi}(\%)$} \\
\hline & CHNP & CHOG & GTS & & ChNP & ChOG & GTS & całości \\
\hline Austria & 10 & 6 & 1 & 17 & 1,64 & 0,84 & 1,64 & 1,23 \\
\hline Belgia & 3 & 11 & 5 & 19 & 0,49 & 1,54 & 8,20 & 1,37 \\
\hline Bułgaria & 0 & 2 & 5 & 7 & 0,00 & 0,28 & 8,20 & 0,51 \\
\hline Chorwacja & 9 & 9 & 0 & 18 & 1,48 & 1,26 & 0,00 & 1,30 \\
\hline Cypr & 1 & 4 & 0 & 5 & 0,16 & 0,56 & 0,00 & 0,36 \\
\hline Czechy & 6 & 23 & 4 & 33 & 0,99 & 3,22 & 6,56 & 2,38 \\
\hline Dania & 0 & 7 & 0 & 7 & 0,00 & 0,98 & 0,00 & 0,51 \\
\hline Estonia & 0 & 0 & 0 & 0 & 0,00 & 0,00 & 0,00 & 0,00 \\
\hline Finlandia & 5 & 2 & 3 & 10 & 0,82 & 0,28 & 4,92 & 0,72 \\
\hline Francja & 103 & 141 & 1 & 245 & 16,91 & 19,72 & 1,64 & 17,69 \\
\hline Grecja & 76 & 30 & 0 & 106 & 12,48 & 4,20 & 0,00 & 7,65 \\
\hline Hiszpania & 102 & 89 & 4 & 195 & 16,75 & 12,45 & 6,56 & 14,08 \\
\hline Holandia & 6 & 5 & 4 & 15 & 0,99 & 0,70 & 6,56 & 1,08 \\
\hline Irlandia & 3 & 4 & 0 & 7 & 0,49 & 0,56 & 0,00 & 0,51 \\
\hline Litwa & 1 & 4 & 2 & 7 & 0,16 & 0,56 & 3,28 & 0,51 \\
\hline Luksemburg & 2 & 2 & 0 & 4 & 0,33 & 0,28 & 0,00 & 0,29 \\
\hline Łotwa & 1 & 2 & 3 & 6 & 0,16 & 0,28 & 4,92 & 0,43 \\
\hline Malta & 0 & 0 & 0 & 0 & 0,00 & 0,00 & 0,00 & 0,00 \\
\hline Niemcy & 12 & 77 & 0 & 89 & 1,97 & 10,77 & 0,00 & 6,43 \\
\hline Polska & 8 & 22 & 9 & 39 & 1,31 & 3,08 & 14,75 & 2,82 \\
\hline Portugalia & 64 & 73 & 1 & 138 & 10,51 & 10,21 & 1,64 & 9,96 \\
\hline Rumunia & 1 & 3 & 0 & 4 & 0,16 & 0,42 & 0,00 & 0,29 \\
\hline Słowacja & 2 & 10 & 7 & 19 & 0,33 & 1,40 & 11,48 & 1,37 \\
\hline Słowenia & 8 & 12 & 3 & 23 & 1,31 & 1,68 & 4,92 & 1,66 \\
\hline Szwecja & 3 & 3 & 2 & 8 & 0,49 & 0,42 & 3,28 & 0,58 \\
\hline W.Brytania & 10 & 40 & 4 & 54 & 1,64 & 5,59 & 6,56 & 3,90 \\
\hline Węgry & 6 & 8 & 1 & 15 & 0,99 & 1,12 & 1,64 & 1,08 \\
\hline Włochy & 167 & 126 & 2 & 295 & 27,42 & 17,62 & 3,28 & 21,30 \\
\hline Suma & 609 & 715 & 61 & 1385 & 100,00 & 100,00 & 100,00 & 100,00 \\
\hline
\end{tabular}

Źródło: opracowanie własne, na podst. Rolnictwo i rozwój obszarów wiejskich, DOOR - Database of Origin and Registration; www.ec.europa.eu. 
Polska w porównaniu $\mathrm{z}$ innymi europejskimi krajami posiada relatywnie niewiele zarejestrowanych nazw produktów. Na dzień 17 stycznia 2018 r. było ich 39, w tym 8 jako ChNP, 22 jako ChOG i 9 jako GTS, co daje udział wynoszący 2,8\%. Lepiej prezentuje się sytuacja, jeśli uwzględni się tylko grupę nazw produktów zarejestrowanych jako GTS. W tym przypadku na 57 nazw w całej UE, 9 dotyczy polskich produktów, co stanowi niemal $16 \%$.

Tabela 5. Indeks HHI na rynku żywności regionalnej i tradycyjnej wśród państw UE

Table 5. HHI index on the regional and traditional food market among EU countries

\begin{tabular}{c|c}
\hline Oznaczenie & Wartość HHI \\
\hline ChNP & 1604,15 \\
ChOG & 1157,04 \\
GTS & 771,30 \\
Ogółem & 1207,20 \\
\hline
\end{tabular}

Źródło: badania własne.

Udział zarejestrowanych nazw produktów pochodzących spoza Unii Europejskiej jest bardzo mały (poniżej 30). Wśród nich najwięcej pochodzi z Chin (10), Mauritiusa (4), Tajlandii (4), Turcji (3), Norwegii (2) i po jednym z Kolumbii, Dominikany i Wietnamu.

Przyjmując unijne kryteria interpretacji wskaźnika HHI, rynek żywności regionalnej i tradycyjnej w krajach UE należy uznać za umiarkowanie skoncentrowany (tab. 5). W największym stopniu zostało to uwidocznione w przypadku grupy oznaczeń ChNP, gdzie analizowany indeks przyjął wartość 1604,15 . Natomiast w grupie produktów zarejestrowanych jako GTS rynek można uznać za nieskoncentrowany. Ze względu jednak na marginalny udział tej grupy w badanej próbie, wynik ten nie ma znaczącego wpływu na ocenę koncentracji całego rynku.

\section{Koncentracja produkcji żywności regionalnej i tradycyjnej w Polsce}

Analizie poddano koncentrację produkcji certyfikowanej żywności regionalnej i tradycyjnej w Polsce z uwzględnieniem poszczególnych województw. Wyniki badania dowiodły, że producenci tej grupy produktów żywnościowych są silnie skoncentrowani w dwóch województwach: mazowieckim i wielkopolskim, w których w 2018 r. zlokalizowanych było odpowiednio 53,1\% i 17,2\% ogółu producentów (tab. 6).

Silna koncentracja producentów determinuje wartość wskaźnika HHI, która w 2017 r. wyniosła 2 672,51, a rok później była jeszcze większa i osiągnęła wartość 3 295,92 (tab. 7). Tak wysokie wartości oznaczają jednoznacznie wysoką koncentrację polskiego rynku w tym zakresie, nawet jeśli uwzględni się bardziej restrykcyjne kryteria amerykańskie.

Niższe wartości HHI odnotowano w przypadku analizy koncentracji produktów ChNP, ChOG, GTS. Porównując wyniki uzyskane dla krajów UE, zauważa się ich zbieżność z rynkiem polskim. Uwagę zwraca jednak wyraźnie zróżnicowanie wartości HHI $\mathrm{w}$ przypadku rozkładu producentów i produktów. Wynika to $\mathrm{z}$ faktu, że niektóre $\mathrm{z}$ certyfikowanych produktów cieszą się bardzo dużym zainteresowaniem producentów: $\mathrm{w}$ województwie mazowieckim są to jabłka grójeckie, a w województwie wielkopolskim rogale świętomarcińskie. 
Tabela 6. Liczba producentów i produktów ChNP, ChOG, GTS w Polsce (wg województw) na dzień 12.01.2018

Table 6. Number of products classes registered as PDOs, PGIs and GTS in Poland - (as of 12 January 2018)

\begin{tabular}{|c|c|c|c|c|c|c|c|c|}
\hline \multirow{2}{*}{ Województwo } & \multicolumn{4}{|c|}{2018} & \multicolumn{4}{|c|}{2017} \\
\hline & Producenci & $\mathrm{Pi}(\%)$ & Produkty & $\operatorname{Pi}(\%)$ & Producenci & Pi (\%) & Produkty & $\mathrm{Pi}(\%)$ \\
\hline dolnośląskie & 2 & 0,29 & 1 & 7,89 & 2 & 0,33 & 1 & 2,44 \\
\hline $\begin{array}{l}\text { kujawsko- } \\
\text { pomorskie }\end{array}$ & 0 & 0,00 & 0 & 0,00 & 0 & 0,00 & 0 & 0,00 \\
\hline lubelskie & 7 & 1,03 & 3 & 7,89 & 8 & 1,31 & 3 & 7,32 \\
\hline lubuskie & 1 & 0,15 & 1 & 2,63 & 1 & 0,16 & 1 & 2,44 \\
\hline łódzkie & 42 & 6,19 & 1 & 2,63 & 39 & 6,39 & 1 & 2,44 \\
\hline małopolskie & 72 & 10,77 & 10 & 21,05 & 96 & 15,74 & 11 & 26,83 \\
\hline mazowieckie & 360 & 53,10 & 4 & 10,53 & 272 & 44,59 & 4 & 9,76 \\
\hline opolskie & 10 & 1,47 & 2 & 2,63 & 9 & 1,48 & 2 & 4,88 \\
\hline podkarpackie & 6 & 0,88 & 1 & 2,63 & 6 & 0,98 & 1 & 2,44 \\
\hline podlaskie & 14 & 2,06 & 3 & 7,89 & 13 & 2,13 & 3 & 7,32 \\
\hline pomorskie & 26 & 3,83 & 1 & 2,63 & 26 & 4,26 & 1 & 2,44 \\
\hline śląskie & 13 & 1,77 & 5 & 10,53 & 14 & 2,30 & 5 & 12,20 \\
\hline świętokrzyskie & 2 & 0,29 & 1 & 2,63 & 2 & 0,33 & 1 & 2,44 \\
\hline $\begin{array}{l}\text { warmińsko- } \\
\text { mazurskie }\end{array}$ & 0 & 0,00 & 0 & 0,00 & 0 & 0,00 & 0 & 0,00 \\
\hline wielkopolskie & 117 & 17,26 & 5 & 13,16 & 116 & 19,02 & 5 & 12,20 \\
\hline $\begin{array}{l}\text { zachodniopom } \\
\text { orskie }\end{array}$ & 6 & 0,88 & 1 & 5,26 & 6 & 0,98 & 1 & 4,88 \\
\hline Suma & 678 & 100 & 39 & 100 & 610 & 100 & 40 & 100 \\
\hline
\end{tabular}

Źródło: opracowanie własne na podstawie danych Inspekcji Jakości Handlowej Artykułów Rolno-Spożywczych.

Rynek żywności regionalnej i tradycyjnej w Polsce charakteryzuje się dużą liczbą mikro i małych przedsiębiorstw, których szanse rynkowe powiązane są ze zmianami w zachowaniach konsumentów zainteresowanych żywnością wysokiej jakości (Jakubowska, Wierzejski, 2017). Istnieje jednak problem z identyfikacją tych produktów. Konsumenci nie potrafią nazwać produktów typowych dla swojego regionu, co wskazuje na potrzebę edukacji w tym zakresie (Wilczyńska, 2017).

Tabela 7. Indeks HHI na rynku żywności regionalnej i tradycyjnej w Polsce

Table 7. HHI index on the regional and traditional food market in Poland

\begin{tabular}{l|cc}
\hline \multirow{2}{*}{ Wyszczególnienie } & \multicolumn{2}{|c}{ Wartość HHI } \\
\cline { 2 - 3 } & 2017 & 2018 \\
\hline Producenci & 2672,51 & 3295,92 \\
Produkty & 1302,80 & 1237,50 \\
\hline
\end{tabular}

Źródło: badania własne. 


\section{Wnioski}

Rynek UE charakteryzuje się już względną dojrzałością w obszarze obecności i dostępności tradycyjnych i regionalnych produktów żywnościowych. Przeprowadzone badania wskazują jednak, że rynek ten jest stosunkowo mocno skoncentrowany. Odnotowany wskaźnik HHI na poziomie 1207 wskazuje, że większość zarejestrowanych oznaczeń geograficznych produktów pochodzi tylko z kilku krajów - są to kraje basenu morza Śródziemnego, na które przypada niemal trzy czwarte wszystkich unijnych rejestracji. Oznacza to, że kraje ze środkowej i północnej Europy, które również dysponują bogatymi zasobami w zakresie tradycji wytwarzania żywności, charakteryzują się mniejszą aktywnością w badanym obszarze. Istnieje zatem potencjał do rozwoju w tym sektorze gospodarki europejskiej. Wniosek ten dotyczy również Polski, która posiada niewielki udział $\mathrm{w}$ analizowanym rynku. W ujęciu regionalnym w Polsce odnotowano względnie wysoką koncentrację - HHI dla zarejestrowanych produktów wyniósł 1237 . Wyraźnie wyższą wartość obliczono dla koncentracji producentów tych produktów. Uzyskana wartość HHI równa 3295 wynika z faktu, że aż 70\% producentów wywodzi się z dwóch województw: mazowieckiego i wielkopolskiego.

Wydaje się, że sukces rynkowy wybranych tradycyjnych i regionalnych produktów żywnościowych na polskim rynku może stać się stymulantą do rozwoju komercyjnego kolejnych produktów, również w innych regionach kraju. Ten segment rynku żywności w Polsce wzbudza rosnące zainteresowanie konsumentów, jednakże jego rozwój jest bardzo powolny. Mali producenci nie mają szans konkurowania z dużymi zakładami produkcyjnymi, o ile nie zjednoczą sił i nie zwrócą większej uwagi na promocję swoich wyrobów. Jak pokazują analizy, coraz więcej polskich produktów ubiega się o wpis do rejestrów chronionych oznaczeń geograficznych, co powinno być sygnałem do intensyfikacji działań promocyjnych i edukacyjnych w tym zakresie. Konsumencka świadomość istnienia oznaczeń geograficznych żywności regionalnej i tradycyjnej jako gwarancji zakupu produktów określonej jakości i miejsca pochodzenia, może przyczynić się do zwiększenia ich sprzedaży i zapewnienia lojalności konsumentów.

\section{Literatura}

Campbell, J., DiPietro, R.B., Remar, D. (2014). Local foods in a university setting: Priceconsciousness, product involvement, price/quality inference and consumer's will-ingness-to-pay. International Journal of Hospitality Management, 42, 39-49.

Dansero, E., Puttilli, M. (2013). Multiple territorialities of alternative food networks: six cases from Piedmont, Italy. Local Environment. The International Journal of Justice and Sustainability, 19(6), 626-643.

European Commission (2013). Study on the value of EU GIS. Pobrane 24 maja 2018 z: http://ec.europa.eu/agriculture/external-studies/value-gi_en.htm

Feldmann, C., Hamm, U. (2015). Consumers perceptions and preferences for local food: A review. Food Quality and Preference, 40, 152-164.

Fernández-Ferrín, P., Calvo-Turrientes, A., Bande, B., Artaraz-Miñón, M., Galán-Ladero, M. (2018). The valuation and purchase of food products that combine local, regional and traditional features: The influence of consumer ethnocentrism. Food Quality and Preference, 64, 138-147.

Gellynck X., Banterle A., Kuhne B., Carraresi L., Stranieri S. (2012). Market orientation and marketing management of traditional food producers in the EU. British Food Journal, 114(4), 481-499.

Grebowiec, M. (2017). Produkty regionalne i tradycyjne jako element budowania konkurencyjnej oferty produktów żywnościowych w Polsce i innych krajach Europy (Regional and Traditional Products as an 
Element of Building a Competitive Food Product Offer in Poland and Other European Countries). ZN SGGW. Problemy Rolnictwa Swiatowego, 17(2), 65-80.

Gulbicka, B. (2014). Żywność tradycyjna i regionalna w Polsce (Traditional and regional food in Poland). Instytut Ekonomiki Rolnictwa i Gospodarki Żywnościowej.

HORIZON, Market Intelligence, 2016. Pobrane 24 maja 2018 z: https://ahdb.org.uk/knowledge-library/horizonthe-impact-of-brexit-on-protected-food-names-6-december-2016.

Horizontal Merger Guidelines. (2010). U.S. Department of Justice and Federal Trade Commission. Pobrane 24 maja 2018 z: https://www.justice.gov/sites/default/files/atr/legacy/2010/08/19/hmg-2010.pdf.

Jakubowska, D., Wierzejski, T. (2017). Aspects of the innovative activity of traditional food manufacturers as illustrated by the example of the warmińsko-mazurskie voivodeship. Journal of Agribusiness and Rural Development, 3(45), 563-571.

Kumpulainen, T., Vainio, A., Sandell, M., Hopia, A. (2018). How young people in Finland respond to information about the origin of food products: The role of value orientations and product type. Food Quality and Preference, 68, 173-182.

Kwiatkowska, E.M. (2014). Miary koncentracji - teoria a praktyka ich wykorzystania przez organy regulacyjne na rynkach telekomunikacyjnych (Measures of Market Concentration - Theory and Practice of Their Use by Regulatory Authorities in the Telecommunications Markets). Metody Ilościowe w Badaniach Ekonomicznych, 15(3), 189-198.

Lobb, A.E., Mazzocchi, M. (2007). Domestically produced food: Consumer perceptions of origin, safety and the issue of trust. Acta Agriculturae Scandinavica, Section Food Economics, 4(1), 3-12.

Matczak, M. (2016). Wykorzystanie strukturalnych miar koncentracji w analizie konkurencyjności rynku morskich przewozów kontenerowych (Concentration Measures in the Process of Identification of Competitiveness Level of Global Seaborne Container Transport Market). Problemy Transportu i Logistyki, 3(35), 111-119.

Motta, V., Sharma, A. (2016). Benefits and transaction costs of purchasing local foods in school districts. International Journal of Hospitality Management, 55,81-87.

Pieniak, Z., Verbeke, W., Vanhonacker, F., Guerrero, L., Hersleth, M. (2009). Association between traditional food consumption and motives for food choice in six European countries. Appetite, 53 (1), 101-108.

Stanciu, S. (2015). How Traditional is the European Union in the Agro-food Production? Economics and Applied Informatics, 3, 18-24.

Wilczyńska, A. (2107) Uwarunkowania decyzji nabywczych na rynku żywności regionalnej i tradycyjnej (Determinants of Purchasing Decisions in the Regional and Traditional Food Market). Handel Wewnetrzny, $1(366), 401-412$

Wytyczne w sprawie oceny horyzontalnego połączenia przedsiębiorstw na mocy rozporządzenia Rady w sprawie kontroli koncentracji przedsiębiorstw (2004/C31/03), (Guidelines on the assessment of horizontal mergers under the Council Regulation on the control of concentrations between undertakings) (2004/C 31/03) Pobrane 24 maja 2018 z: https://eur-lex.europa.eu/legal-content/PL/TXT/?uri=celex:52004XC0205(02).

\section{Do cytowania / For citation:}

Jakubowska D., Wierzejski T. (2018). Ocena koncentracji produkcji żywności regionalnej i tradycyjnej w Polsce i krajach Unii Europejskiej. Problemy Rolnictwa Światowego, 18(3), 144-155; DOI: 10.22630/PRS.2018.18.3.73

Jakubowska D., Wierzejski T. (2018). Evaluation of Market Concentration of Regional and Traditional Food Production in Poland and European Union Countries (in Polish). Problems of World Agriculture, 18(3), 144-155; DOI: 10.22630/PRS.2018.18.3.73 